\title{
COVID-19 AND CONSUMER BEHAVIOUR: A REVIEW OF RECENT LITERATURE
}

\author{
M. Olumekor, S.N. Polbitsyn \\ Ural Federal University, Yekaterinburg, Russian Federation
}

COVID-19 has impacted all areas of our lives. It has caused an increase in the mortality and morbidity rates of countries around the world, and an increase in domestic violence and mental health issues, among others. It has also made an unprecedented - and likely lasting - impact on the economy, particularly on the behavior of consumers.

This article provides an excellent review of recent data, research and literature into how COVID-19 is contributing to changing consumer habits in Russia and around the world. Among others, our research found a profound shift in the buying habits of Russian customers, who not only shopped online at historic levels, but also significantly increased their online purchases of things like food, drinks, cosmetic products, etc.

This article is relevant for entrepreneurs, business leaders, policy makers and everyone seeking to understand the changing preferences of consumers.

Keywords: consumer behavior, COVID-19, e-commerce, Russian economy, pandemic, review paper, online shopping, e-tailing.

\section{Introduction}

Pandemics and epidemics have always influenced all spheres of human society. Le Goff (1988) argued that the Spanish Flu and Cholera outbreak was directly responsible for the destruction of food distribution and economic activity, eventually leading to famine. And when making forecasts for the risks associated with a future pandemic and its economic impact, Fan et al. (2017) estimated annual losses of about $\$ 500$ billion, totalling about $0.6 \%$ of global income. In a similar earlier study by the Commission on a Global Health Risk Framework for the Future led by Sands et al. (2016), researchers found that a future pandemic would cost the global economy over $\$ 6$ trillion in the 21 st century. Research from the US Institute of Medicine (2004), estimated the Severe Acute Respiratory Syndrome (SARS) epidemic to have caused a $\$ 40$ billion dollars loss to the global economy, while the MERS virus - Middle East Respiratory Syndrome caused a $54 \%$ drop in South Korean tourism (Czosnek, 2018). The real impact of COVID-19 was far more devastating than most experts predicted. It was socially, economically and psychologically disruptive, and its impact has far outweighed the impact of any modern virus.

Coronavirus or COVID-19 has changed our entire lives in unprecedented ways. It was officially declared a pandemic by the World Health Organization (2020), and countries around the world - including Russia - resorted to lockdowns and strict social distancing measures to counter the spread of the virus. These measures significantly affected the lives of people in different ways. Horsesh and Brown (2020) reported a spike in mental health problems and traumatic stress. This was buttressed by the findings of Holmes et al. (2020), Brooks et al. (2020), and Retti and Daniels (2021). COVID-19 is also poised to impact population growth, and the mortality and morbidity rates of countries (Pfefferbaum \& North, 2020). And there has been a marked increase in domestic violence and disagreements between neighbours as a result of the pandemic (Campbell, 2020).

Moreover, COVID-19 also created a state of uncertainty across the global economy and in the financial condition of people (Rettie \& Daniels, 2021). During the first and second waves of the virus, many businesses were forced to temporarily or permanently close down, forcing them to layoff workers. This in turn created a situation in which neither the employers nor employees were in good financial condition (Akkermans et al., 2020; Gallup, 2020; Hamouche, 2020; Sergent \& Stajkovic, 2020). This lack of excess disposable income, alongside economic uncertainty and a lack of social interaction, all contributed to changing the consumption behaviour of people in Russia and around the world.

This paper explores the impact of COVID-19 on buying behaviour by synthesising the recent literature on the subject.

\section{COVID-19 and Consumer Behaviour}

Consumer behaviour is the sub-field of marketing concerned with studying the decision making process of consumers, including the factors influencing the decision to buy, use and dispose of goods and services. Consumer behaviour doesn't just study what a consumer buys, but the reason behind the purchase and the frequency of purchase (Schiffman, et al, 2007). The internal and external environment has always played a significant role in the decision making process of consumers (Wright, 2006), and Howard and Sheth (1969) argued that human consumption is always influenced by the time and location of every 


\section{Маркетинг}

consumer. Therefore, it is only fitting that an event as monumental as the coronavirus pandemic would reshape consumer behaviour.

All around the world, there were massive shifts in the buying habits and preferences of consumers. Surveys from consumer data firm, Numerator (2021) showed that in April 2020, more than $90 \%$ of consumers reported a change in shopping behaviour due to the pandemic. Accenture (2020) reported a shift in the purchasing priorities of consumers, with consumers prioritising the most essential needs such as food and hygiene products. While nonessential products experienced a slump. Research from PwC (2020) also found a notable increase in the purchase of essential goods such as frozen foods, perishable and nonPerishable groceries, beverages and household supplies. Consumers also overwhelmingly began to prefer online purchases with home delivery. A similar survey by McKinsey (2020) in India showed that $76 \%$ of Indians were willing to cut back expenses and focus on essential purchases because of the pandemic. This type of behaviour is consistent with the earlier findings of Ragnan, Clyde and Kasturi (2010) who found that in the face of a crisis, consumers usually become more careful with spending and develop a better value for money. In China, Chen et al. (2020) conducted a detailed study into the impact of COVID-19 on consumption by looking at transaction data across hundreds of cities. In Wuhan, which was initially the epicentre of the pandemic, there was a $70 \%$ drop in consumption during the first 3 months of 2020. While in the overall Chinese economy, restaurants experienced a $64 \%$ drop, and travel saw a $59 \%$ contraction in sales. These show that consumers prioritised cooking their own food, likely because they could not go out to eat due to the lockdown.

Data from Accenture (2020) also showed that during the earlier waves of the virus, $73 \%$ of consumers preferred socialising in their homes or in the homes of friends and family, and people began to develop a preference for social media and other online entertainment platforms. According to the New York Times (2020), Facebook experienced a $27 \%$ increase in user traffic, while Netflix and YouTube saw a $16 \%$ and $15 \%$ increase respectively. Furthermore, apps for social interaction like Houseparty and Nextdoor saw $79 \%$ and $73 \%$ increases respectively. The New York Times (2020) also reported an increased preference for video games and a reduced preference for sports. For example, while ESPN saw a $40 \%$ drop in viewership, apps like TikTok and Twitch saw user increases. All of these happened during the earlier waves of the virus. nesses

The rebirth of e-commerce and online busi-

As stated in the previous section, during the height of the pandemic, there was a drastic change in the consumer preferences of people around the world. Online entertainment and social media usage reached historic levels, and videoconferencing apps like Zoom and Google Meet achieved total dominance. Zoom in particular became one of the world's leading pandemic success stories with a $326 \%$ increase in sales in 2020 alone (BBC, 2021). Additionally, due to the lockdown imposed to contain the spread of the pandemic and a fear of contracting the virus, global consumers began to buy everything online including groceries like food and drinks. In Russia, e-retail giants like Yandex Lavka, Sbermarket, Ozon and Wildberries all introduced 'safe delivery' systems to meet the desires of consumers. In the United States, egrocery was projected to have grown by $52.9 \%$ in 2020 (eMarketer, 2020). This was similar in countries all over the world.

Furthermore, according to the United Nations Conference on Trade and Development - UNCTAD (2021), global e-commerce rose by $4 \%$. For example, in South Korea, e-commerce sales increased from 1 in 5 people in 2019, to 1 in 4 people in 2020. It was the same in the United Kingdom where e-commerce sales reached $23.3 \%$ and in Australia where it reached 9.4 $\%$. Canadians also increased e-commerce purchases to $6.2 \%$, while China and Singapore reached $24.9 \%$ and $11.7 \%$ respectively. However, not all e-commerce companies experienced growth. People began shopping online more than ever before, but they could not travel or move around freely due to governmental restrictions. Therefore, transport and travel companies like Airbnb, Expedia and Booking all suffered huge losses (UNCTAD, 2021).

Fig. 1 below is a table showing the performance of the world's leading e-commerce companies by looking at their Gross Merchandise Value (GMV).

How COVID-19 reshaped Russian consumer behaviour

According to the World Bank, the COVID-19 pandemic affected every area of the Russian Economy. Unemployment reached its highest level in eight years at $6.3 \%$ and the national poverty rate reached $13.2 \%$ in the second quarter of 2020. Furthermore, about 500 thousand jobs were lost in the manufacturing, construction and retail/hospitality sectors, and like many other countries in the world, the Russian economy experienced a recession in 2020 (World Bank, 2020). However, when compared with other countries, the Russian economy performed relatively better, even in the heights of the pandemic. While Russia experienced a GDP contraction of $3 \%$ in 2020, the world economy contracted by $3.8 \%$, and advanced economies by $5.4 \%$ (World Bank, 2021).

Similar to other countries around the world, COVID-19 completely changed the consumption habits of Russian consumers. And like other countries, the first notable shift for Russian consumers is a significant increase in online activity. Russian e-commerce sales reached historic levels as an increasing number of Russians - including elderly consumers - began to buy more things online. Euro monitor projected Rus- 


\begin{tabular}{|c|c|c|c|c|c|c|c|c|c|}
\hline \multicolumn{2}{|c|}{$\begin{array}{l}\text { Rank by } \\
\text { GMV }\end{array}$} & \multirow[t]{2}{*}{ Company } & \multirow[t]{2}{*}{ HQ } & \multirow[t]{2}{*}{ Industry } & \multicolumn{3}{|c|}{$\begin{array}{l}\text { GMV } \\
\text { (\$ billions) }\end{array}$} & \multicolumn{2}{|c|}{$\begin{array}{l}\text { GMV change } \\
(\%)\end{array}$} \\
\hline 2020 & 2019 & & & & 2018 & 2019 & 2020 & $\begin{array}{l}2018- \\
19\end{array}$ & $\begin{array}{l}2019- \\
20\end{array}$ \\
\hline 1 & 1 & Alibaba & China & E-commerce & 866 & 954 & 1,145 & 10.2 & 20.1 \\
\hline 2 & 2 & Amazon & USA & E-commerce & 344 & 417 & 575 & 21.0 & 38.0 \\
\hline 3 & 3 & JD.com & China & E-commerce & 253 & 302 & 379 & 19.1 & 25.4 \\
\hline 4 & 4 & Pinduoduo & China & E-commerce & 71 & 146 & 242 & 104.4 & 65.9 \\
\hline 5 & 9 & Shopify & Canada & $\begin{array}{l}\text { Internet Media \& } \\
\text { Services }\end{array}$ & 41 & 61 & 120 & 48.7 & 95.6 \\
\hline 6 & 7 & eBay & USA & E-commerce & 90 & 86 & 100 & -4.8 & 17.0 \\
\hline 7 & 10 & Meituan & China & E-commerce & 43 & 57 & 71 & 33.0 & 24.6 \\
\hline 8 & 12 & Walmart & USA & $\begin{array}{l}\text { Consumer goods } \\
\text { retail }\end{array}$ & 25 & 37 & 64 & 47.0 & 72.4 \\
\hline 9 & 8 & Uber & USA & $\begin{array}{l}\text { Internet Media \& } \\
\text { Services }\end{array}$ & 50 & 65 & 58 & 30.5 & -10.9 \\
\hline 10 & 13 & Rakuten & Japan & E-commerce & 30 & 34 & 42 & 13.6 & 24.2 \\
\hline 11 & 5 & Expedia & USA & $\begin{array}{l}\text { Internet Media \& } \\
\text { Services }\end{array}$ & 100 & 108 & 37 & 8.2 & -65.9 \\
\hline 12 & 6 & $\begin{array}{l}\text { Booking } \\
\text { Holdings }\end{array}$ & USA & $\begin{array}{l}\text { Internet Media \& } \\
\text { Services }\end{array}$ & 93 & 96 & 35 & 4.0 & -63.3 \\
\hline 13 & 11 & Airbnb & USA & $\begin{array}{l}\text { Internet Media \& } \\
\text { Services }\end{array}$ & 29 & 38 & 24 & 29.3 & -37.1 \\
\hline & & Companies & & & 2,035 & 2,399 & 2,890 & 17.9 & 20.5 \\
\hline
\end{tabular}

Source: UNCTAD, 2021. GMV = Gross Merchandise Value, also known as Booking Value.

Fig. 1. GMV for the world's top e-commerce companies

sian e-commerce sales to have grown by more than 40 $\%$ in 2020 (Reuters, 2020). For example, in the Far Eastern region of Chukotka, Wildberries - Russia's leading e-commerce store, reported a growth of $490 \%$ between April to October in 2020. In the same time frame, consumers in Ingushetia had increased orders by $385 \%$, and by $239 \%$ in Buryatia.

While e-retail stores like Shopify and Walmart saw $95.6 \%$ and $72.4 \%$ growth respectively, travel and transportation companies like Airbnb and Booking Holdings experienced losses.

In fact, in the first 9 months of 2020, Wildberries had attracted 12 million new customers, while existing customers began to spend more money on the website. But it was not only Wildberries. Ozon experienced an $84 \%$ increase in new active buyers between AprilMay 2020, while Yandex Lavka, a firm specialising in the sales of groceries surpassed 1 million orders, from about 50 thousand less than 1 year ago. Another online grocery shop, Utkonos, reported a quarterly increase of $65 \%$ from the same period in 2019 (Reuters, 2021). And Sbermarket reported a $500 \%$ increase in food orders in the first quarter of 2020 (Statista, 2021).

Russia's extraordinary e-commerce growth did not only happen in specific months or quarters of 2020. The entire year was a historic one. According to figures from Data Insights (2021), Russian ecommerce grew by $58 \%$, reaching 2.7 trillion rubles, and sales of groceries online grew by $250 \%$. Furthermore, about 10 million new customers began shopping online in 2020.

All of these show that a large number of Russians became comfortable with buying groceries like food, drinks and vegetables online. While in previous years Russians felt the need to feel the quality of food prod- 


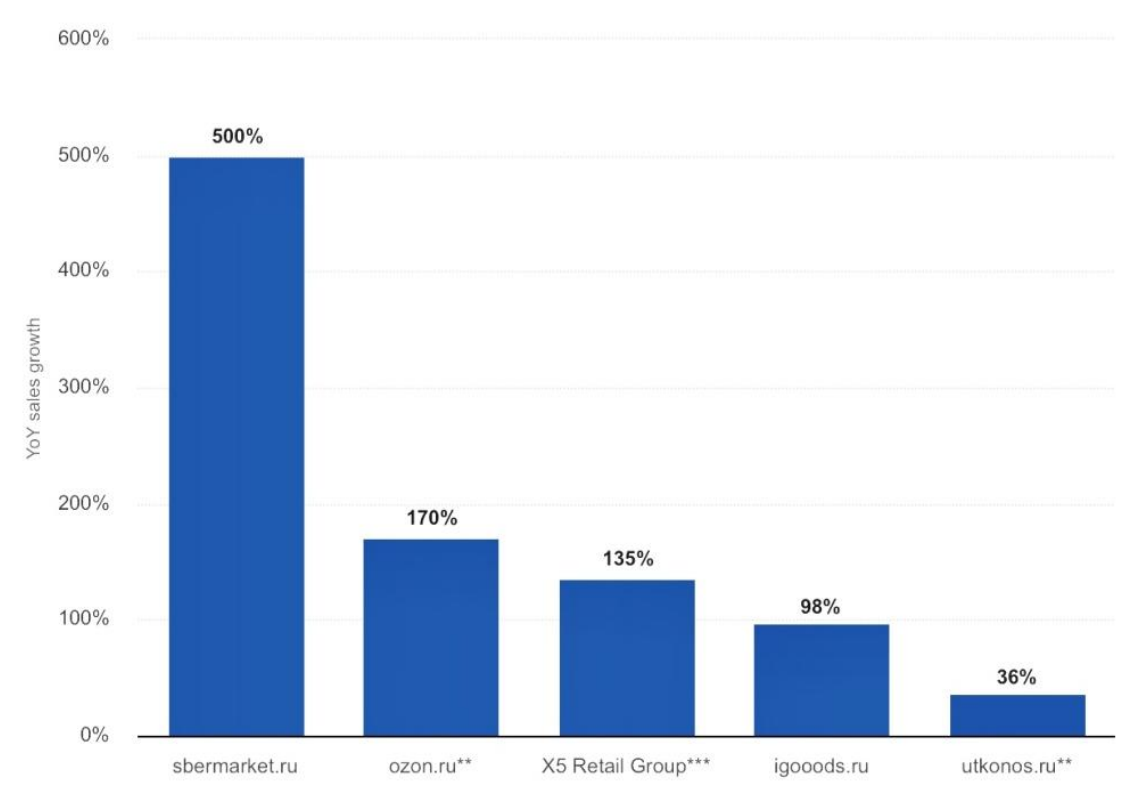

Source: Statista, 2021.

Fig. 2. Impact of COVID-19 on growth of online food sales in Russia in 2020 Quarter 1

ucts in physical stores before buying them, the quality of online shops, backed by huge companies like Sberbank and Yandex, alongside the threat of COVID-19, have made online grocery shopping an increasingly favourable alternative.

Nevertheless, it was not only grocery shopping experiencing astronomical growth. Russians also developed a keen taste for buying other products, particularly cosmetics. In a survey by Migel, $69 \%$ of Russian women between the ages of 18 and 40 reported buying cosmetic products online, and $70 \%$ said they would continue to do so (Migel, 2020).

Ozon reported extraordinary growth of cosmetic sales including a $185 \%$ increase in the sales of lipgloss in 2020 (VC.ru). Wildberries also reported a 3 times increase in its sale of general cosmetic products in April 2020. In the same time period, kits for making cosmetic masks at home increased 44 times year-onyear growth, and thermal water 11 times (Retail.ru).

\section{Conclusion}

This paper succinctly reviewed contemporary research and data into the impact of COVID-19 on the consumption habits and patterns of people. We found that all around the world, including in Russia, people turned to online companies and services to meet basic needs. Consumers turned video conferencing and social media apps like Zoom and TikTok into overnight successes. In Russia, consumers also began to develop a preference for ordering food, drinks and other groceries online. For example, Sbermarket saw a $500 \%$ increase in sales, while Utkonos and Yandex Lavka also experienced astronomical growths.

This paper is relevant for policy makers, business leaders and entrepreneurs looking to understand the ever shifting nature of consumer preferences. However, because this is only a review paper, there is a big opportunity and need for further research on the topic.

\section{References}

Accenture. (2020). Data-driven insights into consumer behavior How is COVID-19 changing the retail consumer?

https://www.accenture.com/_acnmedia/PDF-

130/Accenture-Retail-Research-POV-Wave-Seven.pdf

Akkermans, J., Richardson, J., \& Kraimer, M. L. (2020). The Covid-19 crisis as a career shock: Implications for careers and vocational behavior. Journal of Vocational Behavior, 119, 103434. https://doi.org/ 10.1016/j.jvb.2020.103434

BBC. (2021, March 1). Zoom sees more growth after "unprecedented" 2020. BBC News. https://www.bbc.com/news/business-56247489

Brooks, S. K., Webster, R. K., Smith, L. E., Woodland, L., Wessely, S., Greenberg, N., \& Rubin, G. J. (2020). The psychological impact of quarantine and how to reduce it: rapid review of the evidence. The Lancet, 395(10227), 912-920. https://doi.org/10.1016/S0140-6736(20)30460-8

Campbell, A. M. (2020a). An increasing risk of family violence during the Covid-19 pandemic: Strengthening community collaborations to save lives. Forensic Science International: Reports, 2. https://doi.org/10.1016/j.fsir.2020.100089

Campbell, A. M. (2020b). An increasing risk of family violence during the Covid-19 pandemic: Strengthening community collaborations to save lives. Forensic Science International: Reports, 2. https://doi.org/10.1016/j.fsir.2020.100089 


\begin{tabular}{|c|c|c|c|c|c|c|c|c|}
\hline & & & \multicolumn{2}{|c|}{$\begin{array}{l}\text { Online sales volume } \\
\text { in million rubles }\end{array}$} & \multicolumn{2}{|c|}{$\begin{array}{l}\text { Number of orders } \\
\text { In thousands }\end{array}$} & \multicolumn{2}{|c|}{$\begin{array}{l}\text { Average order value } \\
\text { in rubles }\end{array}$} \\
\hline & & & 2020 & $y-0-y$ & 2020 & $y-0-y$ & 2020 & $y-0-y$ \\
\hline 1 & Wildberries.ru & General online store & 413200 & $96 \%$ & 305000 & $100 \%$ & 1350 & $-2 \%$ \\
\hline 2 & Ozon.ru & General online store & 197000 & $144 \%$ & 73800 & $133 \%$ & 2670 & $5 \%$ \\
\hline 3 & Citilink.ru & Electronics \& household & 132730 & $47 \%$ & 12390 & $23 \%$ & 10710 & $19 \%$ \\
\hline 4 & Dns-shop.ru & Electronics \& household & 116760 & $117 \%$ & 12370 & $82 \%$ & 9440 & $20 \%$ \\
\hline 5 & Mvideo.ru & Electronics \& household & 113200 & $100 \%$ & 8900 & $71 \%$ & 12720 & $17 \%$ \\
\hline 6 & Eldorado.ru & Electronics \& household & 53760 & $95 \%$ & 6400 & $80 \%$ & 8400 & $8 \%$ \\
\hline 7 & Lamoda.ru & Fashion \& accessories & 52970 & $32 \%$ & 14550 & $28 \%$ & 3640 & $4 \%$ \\
\hline 8 & Apteka.ru & Online pharmacy & 50070 & $46 \%$ & 32240 & $48 \%$ & 1550 & $-2 \%$ \\
\hline 9 & Aliexpress.ru & General online store & 49000 & $171 \%$ & 19060 & $218 \%$ & 2570 & $-15 \%$ \\
\hline 10 & Yandex Market & General online store & 44090 & $136 \%$ & 15490 & $159 \%$ & 2850 & $-9 \%$ \\
\hline 11 & Petrovich.ru & DIY, items for the home & 44010 & $50 \%$ & 3820 & $119 \%$ & 11520 & $-32 \%$ \\
\hline 12 & Vseinstrumenti.ru & DIY, items for the home & 42520 & $58 \%$ & 7830 & $106 \%$ & 5430 & $-23 \%$ \\
\hline 13 & Ikea. & DIY, items for the home & 40800 & $175 \%$ & 2550 & $240 \%$ & 16000 & $-19 \%$ \\
\hline 14 & Detmir.ru & Children's goods & 38700 & $142 \%$ & 24300 & $136 \%$ & 1590 & $3 \%$ \\
\hline 15 & Leroymerlin & DIY, items for the home & 37780 & $217 \%$ & 4460 & $254 \%$ & 8470 & $-10 \%$ \\
\hline 16 & Sima-land.ru & General online store & 37400 & $62 \%$ & 4280 & $63 \%$ & 8740 & $-1 \%$ \\
\hline 17 & Svyaznoy.ru & Electronics \& household & 23650 & $18 \%$ & 1840 & $4 \%$ & 12850 & $12 \%$ \\
\hline 18 & Onlinetrade.ru & General online store & 23050 & $22 \%$ & 3560 & $0 \%$ & 6470 & $22 \%$ \\
\hline 19 & Sportmaster.ru & Sports \& leisure & 20110 & $55 \%$ & 6370 & $74 \%$ & 3160 & $-11 \%$ \\
\hline 20 & Shop.mts.ru & Electronics \& household & 19550 & $106 \%$ & 1070 & $81 \%$ & 18270 & $14 \%$ \\
\hline
\end{tabular}

Source: East-West Digital News

Fig. 3. Russia's top-20 e-commerce websites

Czosnek, H. (2018, November 8). Predicting the next global pandemic. Global Risk Insights. https://globalriskinsights.com/2018/11/pandemichealth-pathogen/

Data Insight. (2021). E-commerce in Russia 2020. https://datainsight.ru/sites/default/files/DI_ Ecommerce2020_eng.pdf

East-West Digital News. (2021, May 28). In 2020, Russian e-commerce recorded one of the world's highest growth rates. East-West Digital News. https://www.ewdn.com/2021/05/28/in-2020-russiarecorded-one-of-the-worlds-highest-e-commercegrowth-rates/

eMarketer. (2020). Online grocery sales will increase by nearly $53 \%$ this year. Insider Intelligence. https://www.emarketer.com/content/online-grocerysales-will-increase-by-nearly-53-this-year

Fan, V.Y., Jamison, D.T., \& Summers, L.H. (2018). Pandemic risk: how large are the expected losses? Bulletin of the World Health Organization, 96(2), 129-134. https://doi.org/10.2471/ blt.17.199588

Gallup. (2020, April 22). Record-High $25 \%$ of U.S. Workers Say Job Loss Is Likely. Gallup.com. https://news.gallup.com/poll/308960/record-highworkers-say-job-loss-likely.aspx

Hamouche, S. (2020). COVID-19 and employees' mental health: stressors, moderators and agenda for organizational actions. Emerald Open Research, 2, 15. https://doi.org/10.35241/emeraldopenres.13550.1

Holmes, E.A., O’Connor, R.C., Perry, V.H., Tracey, I., Wessely, S., Arseneault, L., Ballard, C., Christensen, H., Cohen Silver, R., Everall, I., Ford, T., John, A., Kabir, T., King, K., Madan, I., Michie, S., Przybylski, A. K., Shafran, R., Sweeney, A., \& Worthman, C.M. (2020). Multidisciplinary research priorities for the COVID-19 pandemic: a call for action for mental health science. The Lancet Psychiatry, 7(6). https://doi.org/10.1016/s22150366(20)30168-1

Horesh, D., \& Brown, A. D. (2020). Traumatic stress in the age of COVID-19: A call to close critical gaps and adapt to new realities. Psychological Trauma: Theory, Research, Practice, and Policy, 12(4), 331-335. https://doi.org/10.1037/tra0000592

Howard, J. A., \& Sheth, J. N. (1969). The theory of buyer behavior. J. Wiley.

Institute of Medicine, Knobler, S., Mahmoud, A., Lemon, S., Mack, A., Sivitz, L., \& Oberholtzer, K. 
(2004). OVERVIEW. In www.ncbi.nlm.nih.gov. National Academies Press (US). https://www.ncbi.nlm. nih.gov/books/NBK92446/?report=reader

Jacques Le Goff. (1990). Medieval civilization. Wiley-Blackwell.

McKinsey. (2020). Consumer sentiment in India during the coronavirus crisis | McKinsey. Www.mckinsey.com. https://www.mckinsey.com/ business-functions/marketing-and-sales/our-

insights/survey-indian-consumer-sentiment-duringthe-coronavirus-crisis

Migel. (2020). Новая реальность бьютииндустрии: как покупают косметику в период пандемии. Think with Google. https://www.thinkwithgoogle.com/intl/ru-ru/insights-trends/adeffectiveness-research/beauty-new-trends/

Numerator. (2021). The Impact of COVID-19 on Consumer Behavior. Www.numerator.com. https://www.numerator.com/resources/blog/impactcovid-19-consumer-behavior

Pfefferbaum, B., \& North, C. S. (2020). Mental Health and the Covid-19 Pandemic. New England Journal of Medicine,383(6). https://doi.org/ 10.1056/nejmp2008017

PwC. (2020). Evolving priorities: COVID-19 rapidly reshapes consumer behavior. PwC. https://www.pwc.com/us/en/industries/consumermarkets/library/covid-19-consumer-behaviorsurvey.html

Rangan, M. E., Andrew Clyde, and Kasturi. (2010). The New Consumer Frugality. Strategy+Business. https://www.strategy-business.com/ article $/ 00023$ ?gko $=04 \mathrm{ca} 3$

Retail.ru. (2020, May 8). Wildberries: Популярность товаров для красоты выросла в апреле в 3 раза. Retail.ru. https://www.retail.ru/news/wildberries-populyarnost-tovarov-dlya-krasoty-vyrosla-vaprele-v-3-raza-8-maya-2020-194089/

Rettie, H., \& Daniels, J. (2021). Coping and tolerance of uncertainty: Predictors and mediators of mental health during the COVID-19 pandemic. American Psychologist, 76(3), 427-463. https://doi.org/http://dx.doi.org/10.1037/amp0000710

Reuters. (2020, November 19). COVID-19 crisis: a shot in the arm for Russian e-commerce. Reuters. https://www.reuters.com/article/us-russia-ecommercefocus-idUSKBN27Z10Z

Sands, P., Mundaca-Shah, C., \& Dzau, V. J. (2016). The Neglected Dimension of Global Security - A Framework for Countering Infectious-Disease
Crises. New England Journal of Medicine, 374(13), 1281-1287. https://doi.org/10.1056/nejmsr1600236

Schiffman, L.G., \& Leslie Lazar Kanuk. (2007). Consumer behavior. Pearson Prentice Hall.

Sergent, K., \& Stajkovic, A. D. (2020). Women's leadership is associated with fewer deaths during the COVID-19 crisis: Quantitative and qualitative analyses of United States governors. Journal of Applied Psychology, 105(8), 771-783. https://doi.org/10.1037 /ap10000577

Statista. (2021). Russia: online food sales growth due to COVID-19 2020. Statista. https://www.statista.com/statistics/1117601/russia-online-food-salesgrowth-due-to-covid-19/

The New York Times. (2020, April 7). The Virus Changed the Way We Internet. The New York Times. https://www.nytimes.com/interactive/2020/04/07/tech nology/coronavirus-internet-use.html

UNCTAD. (2021). Global e-commerce jumps to $\$ 26.7$ trillion, COVID-19 boosts online sales | UNCTAD. Unctad.org. https://unctad.org/news/globale-commerce-jumps-267-trillion-covid-19-boostsonline-sales

VC.ru. (2020, September 4). Цифровые тренды в bеаит-ритейле, за которыми стоит следить в 2020-2021 годах - Сервисы на vс.ru. Vc.ru. https://vc.ru/services/155733-cifrovye-trendy-vbeauty-riteyle-za-kotorymi-stoit-sledit-v-2020-2021godah

World Bank. (2020). Russia's Economy Loses Momentum Amid COVID-19 Resurgence, Says New World Bank Report. World Bank. https://www.worldbank.org/en/news/press-release/2020/12/16/russiaseconomy-loses-momentum-amid-covid-19resurgence-says-new-world-bank-report

World Bank. (2021). Russia Economic Report. World Bank. https://www.worldbank.org/en/ country/russia/publication/rer

World Health Organization. (2020). WHO Director-General's opening remarks at the media briefing on COVID-19 - 20 March 2020. Www.who.int; World Health Organization. https://www.who.int/directorgeneral/speeches/detail/who-director-general-sopening-remarks-at-the-media-briefing-on-covid-19--20-march-2020

Wright, K. B. (2006). Researching Internet-Based Populations: Advantages and Disadvantages of Online Survey Research, Online Questionnaire Authoring Software Packages, and Web Survey Services. Journal of Computer-Mediated Communication, 10(3), https://doi.org/10.1111/j.1083-6101. 2005.tb00259.x

Michael Olumekor, postgraduate student, Ural Federal University, Yekaterinburg, molumekor@urfu.ru; https://orcid.org/0000-0002-1764-2240

Sergey N. Polbitsyn, Professor, Doctor of Economics, Candidate of Technical Sciences, Ural Federal University, Yekaterinburg.

Received August 2, 2021 
УДК 658

DOI: $10.14529 / \mathrm{em} 210319$

\title{
COVID-19 И ПОВЕДЕНИЕ ПОТРЕБИТЕЛЕЙ: ОБЗОР НОВЕЙШЕЙ ЛИТЕРАТУРЫ
}

\author{
М. Олумекор, С.Н. Полбицын \\ Уральский фредеральный университет, г. Екатеринбург, Россия
}

COVID-19 повлиял на все сферы нашей жизни. Это привело к росту показателей смертности и заболеваемости в странах по всему миру, а также росту насилия в семье и проблем с психическим здоровьем, среди прочего. Это также оказало беспрецедентное и, вероятно, длительное воздействие на экономику, особенно на поведение потребителей.

В этой научной работе представлен отличный обзор последних данных и исследований о том, как COVID-19 способствует изменению потребительских привычек во всем мире. Среди прочего, в процессе работы над статьей мы обнаружили фундаментальный сдвиг в покупательских привычках российских потребителей, которые не только делали покупки онлайн на исторически рекордном уровне, но и значительно увеличили объем своих онлайн-покупок, в частности, продуктов питания, напитков и косметических средств.

Эта статья актуальна для предпринимателей, бизнес-лидеров, политиков и всех, кто стремится понять меняющиеся предпочтения потребителей.

Ключевые слова: поведение потребителей, COVID-19, электронная коммерция, российская экономика, пандемия, обзорная статья, интернет-магазины, электронная торговля.

Олумекор Майкл, аспирант, Уральский федеральный университет (г. Екатеринбург), https://orcid.org/0000-0002-1764-2240, molumekor@urfu.ru

Полбицын Сергей Николаевич, профессор, доктор экономических наук, кандидат технических наук, Уральский федеральный университет (г. Екатеринбург).

Поступила в редакцию 2 августа 2021 2.

\section{ОБРАЗЕЦ ЦИТИРОВАНИЯ}

Olumekor, M. COVID-19 and Consumer Behaviour: A Review of Recent Literature / M. Olumekor, S.N. Polbitsyn // Вестник ЮУрГУ. Серия «Экономика и менеджмент». - 2021. - Т. 15, № 3. - С. 183-189. DOI: $10.14529 / \mathrm{em} 210319$

\section{FOR CITATION}

Olumekor M., Polbitsyn S.N. COVID-19 and Consumer Behaviour: A Review of Recent Literature. Bulletin of the South Ural State University. Ser. Economics and Management, 2021, vol. 15, no. 3, pp. 183-189. DOI: $10.14529 / \mathrm{em} 210319$ 